\title{
USKONTOTIETEILIJÄ ASTUU ULOS KAAPISTA
}

\section{ILKKA PYYSIÄINEN: JUmalaa ei ole. Vastapaino, Tampere 2010.}

Tiedonsosiologia on perinteisesti tutkinut erilaisia yhteiskunnassa vallitsevia uskomuksia ottamatta kantaa siihen, miten tosia tai epätosia nämä uskomukset ovat. Uskontotiede noudattaa yleensä samaa strategiaa eikä ryhdy pohtimaan sitä, ovatko uskonnolliset uskomukset tosia vai kenties pahemman kerran erheellisiä. Ilkka Pyysiäisen tuore kirja muodostaa tässä kaanonissa virkistävän poikkeuksen, sillä jo sen otsikko kieltää Jumalan olemassaolon.

Pyysiäisen ominta alaa on kognitiivinen uskontotiede, joka selittää ihmisen uskonnollisuutta inhimillisen tiedonkäsittelyn ominaislaadun avulla. Tällä tieteenalalla on keskusteltu muun muassa hypoteesista, jonka mukaan jumaluskomukset saattavat olla seurausta hyperaktiivisesta intentioiden havaitsemismekanismista. Ihmisille kun on luonteenomaista olettaa, että kun jotain tapahtuu, tämän tapahtumisen takana täytyy olla jokin intentionaalinen toimija. Siten esimerkiksi maailmankaikkeuden synty vaikuttaa tapahtumalta, joka vaatii taakseen jonkinlaisen toimijan. Muut lajit taas eivät kunnolla kykene postuloimaan intentioita silloinkaan, kun niitä olisi oikeasti "havaittavissa" (vaikkei intentioita koskaan voikaan suoraan havaita), mutta ihmiset siis tuppaavat kuvittelemaan toimijoita sinnekin, missä niitä ei ole. Pyysiäisen teos ei kuitenkaan ole kognitiivisen uskontotieteen oppikirja, vaan räväkkä pamfletti, joka on saanut inspiraationsa Richard Dawkinsin, Sam Harrisin ja Christopher Hitchensin poleemisista uskontokirjoista. Pyysiäinen tekee kuitenkin selvän eron Dawkinsiin, sillä hänen kritiikkinsä "kohdistuu nimenomaan uskonnollisiin uskomuksiin, ei uskoon elämäntapana" (s.7). Dawkinsia kun on kritisoitu siitä, että hän ei tätä eroa tee.

Kirja alkaa historiallisella katsauksella, jossa käsitellään muun muassa helvetin historiaa. Uskomus helvettiin saattaa Pyysiäisen mukaan liittyä ihmisten kokemuksiin tulivuorenpurkauksista: "jos kerran maan uumenista syöksyy tulta ja tulikiveä, totta maar sitä on siellä silloin oltava" (s. 12). Vanhassa testamentissa ei kuitenkaan ole sen paremmin viimeistä tuomiota kuin taivasta ja helvettiäkään. Ajatus sielun kuolemattomuudesta saattaakin olla Platonin ja uusplatonistien perua, sillä näille veijareille ajatus "tyhjiin raukeamisesta" ei käynyt laatuun.

Kirjan läpitunkeva teema liittyy siihen, millaisia uskonnolliset uskomukset oikein ovat. Pyysiäisen mukaan luonnontieteilijän kanssa keskusteleva teologi "sanoo uskoaan vertauskuvalliseksi, mutta harjoittaessaan uskontoaan hän suhtautuu siihen enemmän tai vähemmän kirjaimellisesti" (s. 25). Viittaamalla uskonnon vertauskuvallisuuteen voidaan yrittää väistää kriitikoiden huomautukset, mutta suurin osa uskovaisista kokee tällaisen vertauskuvallisen asenteen vieraaksi. Lisäksi voidaan myös väittää, että yritykset tulkita uskontoa vertauskuvallisesti ovat nimenomaan seurausta tieteen edistymisestä. Uskonnolla kun on tieteen ansiosta yhä pienenevä rooli maailman selittäjänä. Pyysiäisen mukaan uskontoa voidaan yrittää puolustaa muokkaamalla jumalakäsitystä loputtomiin niin, että välitön konflikti tieteen kanssa vältetään (esim. Jumala on aina jotenkin "kaiken takana"), mut- ta tällainen menettely "tekee kuitenkin uskonnosta niin abstraktia, että sen käytännöllinen relevanssi häviää" (s. 134).

Voidaan myös ihmetellä joskaan Pyysiäinen ei itse näin tee - mitä olisivat sellaiset uskomukset, jotka eivät viittaa mihinkään. Voiko ylipäätään olla olemassa sellaisia uskomuksia, joiden puolesta tai joita vastaan mikään evidenssi ei edes periaatteessa voisi puhua? Esimerkiksi kanadalaisfilosofi Cheryl Misak on vastannut tähän kysymykseen kieltävästi, sillä hänen mukaansa uskomukset ovat määritelmällisesti kytköksissä aina johonkin viittauskohteeseen. Uskonnon tapaukseen sovellettuna Misakin kanta näyttäisi tukevan Pyysiäisen väitteitä. Kaikesta evidenssistä irti kytkettyjä uskomuksia - "uskoa" - ei tällaisen näkemyksen mukaan oikeastaan voi olla olemassa. Tämä ei luonnollisestikaan tarkoita sitä, että referenssin täytyisi aina olla yksiselitteisen selvä vastaavuussuhde.

Itse asiassa lienee niin, että uskovaiset eivät yleensä kiellä evidenssin yleistä merkitystä, vaan suhtautuvat siihen hyvin valikoivasti ja puolueellisesti: positiivista evidenssiä (esim. Jeesuksen oletetut käärinliinat) vastaanotetaan mieluusti, mutta kaikki negatiivinen evidenssi pyritään kiistämään. Uskomukset siis muuttuvat "uskoksi" vasta silloin, kun ne ovat vaarassa horjua. Tämä taipumus on sinällään hyvin ymmärrettävä, sillä sosiaalipsykologiassa on jo pitkään tiedetty, että inhimilliselle päättelylle on ominaista pyrkimys omien uskomusten pönkittämiseen. Tästä taipumuksesta johtuen havaintomme ovat yleensä hyvin valikoivia: näemme, mitä haluamme.

Varsinainen kognitiotiede näyttelee Pyysiäisen kirjassa 
melko pientä roolia. Joitakin selityksiä hän kuitenkin antaa erilaisille uskonnollisille ilmiöille. Esimerkiksi ajatus ylösnousemuksesta liitetään siihen, että "ihmisillä on voimakas kokemus siitä, että he ovat jotakin enemmän kuin oma ruumiinsa. [...] Sielua tai minää taas on vaikea ajatella antamatta sille jonkinlaista aineellista hahmoa" (s. 35). Ajatuksen taustalla olisi siis kokemus ruumiin ja tietoisen minuuden dualismista ja se, että "sielua" tai vastaavaa on hyvin vaikea kuvitella ilman ruumiin sille antamaa muotoa. Näin ollen hautajaisseremoniat liittyvät siihen dilemmaan, ettemme oikein tiedä, tulisiko kuollutta ruumista käsitellä persoonana vai esineenä.

Pyysiäinen esittää kiinnostavia pohdintoja rituaalien luonteesta. Monia rituaaleja kuten esimerkiksi rukoilemista - luonnehtiva pakonomaisuus ja toisto saattaa olla "reaktio tilanteeseen, jossa jokin vaara tuntuu uhkaavan, mutta vaaran tarkemmasta luonteesta ei ole tietoa" (s. 39). Tällaisessa tilanteessa tuntuu siltä, että jotakin olisi tehtävä, vaikkei olekaan selvää, miksi näin tulisi tehdä. Uskonnolliset rituaalit eivät ole varsinaisia psykologisia pakkooireita, mutta "ne herättävät meissä tietoisia ja tiedostamattomia muistoja todellisista vaaratilanteista ja vahinkojärjestelmien laukeamisesta" ja siksi ne "tuntuvat aivan spontaanisti jotenkin pakottavilta ja luontevilta" (s. 41).

Tällaisiin pohdintoihin voisi rukoilemisen osalta lisätä inhimillisen sosiaalisuuden intersubjektiivisen erikoislaatuisuuden mahdollisen vaikutuksen. Kuten jo alussa totesin, meillä on taipumus nähdä toimijoita sielläkin, missä toimijoita ei ole. Tähän liittyy G. H. Meadin aikoinaan tekemä huomio sii- tä, että minuutemme kehittyy jatkuvassa sisäisessä ja ulkoisessa vuoropuhelussa toisten ihmisten kanssa. Ihmiset miettivät yksin ollessaankin muiden mahdollisia intentioita ja asenteita ja tällaisesta muiden imaginaarisesta läsnäolosta ei ole enää pitkä matka erilaisten kuvitteellisten olentojen tai kuolleiden läheisten kanssa "keskustelemiseen". Intersubjektiivinen sosiaalisuus saattaa siis olla yksi selitys sille, miksi "jotkut ystävistämme menevät toisinaan tiettyyn paikkaan puhumaan näkymättömälle olennolle, joka on kaikkialla ja tietää etukäteen, mitä he aikovat sanoa" (s. 43), kuten Pyysiäinen viittaa Pascal Boyerin sarkastiseen huomioon.

Toisinaan esitetään, että moraali ei ole mahdollinen ilman uskontoa. Pyysiäsen vastaväite kuuluu, että moraali on osa inhimillistä kognitiota ja niin ollen uskonto toimii vain yhtenä moraalin ja sen velvoittavuuden ilmaisutapana. Hän on kuitenkin sitä mieltä, että vaikka moraali onkin evoluution tuote, se ei kuitenkaan suoraan ole johdettavissa evoluutiosta. Filosofinen pohdinta, siis eettinen reflektio, on nimittäin vienyt tämän kyvyn uuteen ulottuvuuteen. Silti on hyvä korostaa sitä, että moraali perustuu yhteisille intentioille eli vastavuoroisuuden, auttamisen ja informaation jakamisen normeille, jotka tulevat ihmisille kirjaimellisesti kuin luonnostaan (toisin kuin muille kädellisille, joiden kommunikaatio perustuu lähinnä imperatiiveihin).

Pyysiäisen mukaan voidaan jopa väittää, että "mikäli Jumala olisi olemassa, kaikki olisi sallittua" (s. 164). Näin on siitä syystä, että tällöin oikein olisi se, mitä Jumala sattuisi kulloinkin käskemään - riippumatta käskyjen moraalisuudesta.
Uskovaisten mielestä Jumala ei tietenkään käske tekemään mitään väärää, mutta Pyysiäistä tämä argumentti ei vakuuta, sillä se itse asiassa edellyttää jonkin Jumalasta riippumattoman oikean ja väärän arviointikeinon - ja on siten ristiriidassa sen kanssa, että moraali olisi Jumalasta lähtöisin.

Pyysiäisen kirja saa luultavasti monet syyttämään sitä skientismistä. Hänen asennoitumisensa tieteen mahdollisuuksiin on kuitenkin tervejärkisen maltillinen. Pyysäisen mukaan ainoastaan matematiikka pyrkii todistamaan jotain, kun taas luonnontieteet keräävät havaintoja, joita selitetään teorioilla. Tiede ei siis pysty todistamaan sitä, että jumalaa ei ole olemassa; jonkin olemattomuutta kun ei voida ylipäätään osoittaa. Toisaalta kaikki saatavilla oleva evidenssi viittaa siihen, että jumalaa ei ole, ja lisäksi on niin, että "uskovatkaan eivät usko kaikkea, minkä olemattomuutta ei voida todistaa: kunnon kristitty ei usko peikkoihin eikä menninkäisiin vaikka on periaatteessa mahdollista, että niitä on olemassa" (s. 37). Näin ollen agnostikko on oikeastaan turhan sovittelevainen arviossaan. Ateisti kun ei ole mitenkään lopullisesti ja dogmaattisesti sitoutunut jumalan olemattomuuteen, vaikka uskookin, että tällä hetkellä kaikki puhuu tällaisen näkemyksen puolesta.

Pahoin pelkään, että Pyysiäistä saatetaan silti pitää skientistinä. Tieteen saavutuksia ja näiden saavutusten suurta vaikutusta maailmankuvaamme ei toki käy kiistäminen, mutta tieteen erinomaisuuden sijasta on syytä painottaa sitä, että tiede on normaalin päättelyn jatke. Arkipäättelykin nimittäin nojaa "evidenssin" vakuuttavuuteen ja erilaisiin havaintolähteisiin. Tiede vain 
tekee saman tempun huomattavasti systemaattisemmin, erityisiä havaintovälineitä ja päättelytekniikoita apuna käyttäen sekä havaintojen mahdollisia virhelähteitä kontrolloiden. Voidaan siis sanoa, että tiede on vain "terveen järjen" jatke eikä esimerkiksi mikään erityinen oma metodinsa.

Pyysiäisen piikittelystä saavat osansa sekä kulttuurintutkijat että humanistit. Hänen mukaansa monet "humanistit ovat [...] niin luonnosta vieraantuneita, että [he] kuvittelevat luontodokumenttien sisältävän julmia saalistuskohtauksia vain siksi, että yhteiskunnassa vallitsee 'darwinistinen' ideologia" (s. 26). Sitaatin irvailun kohde lienee eräs vihreä journalistihistorioitsija. Vielä enemmän kölin ali vedetään historioitsija Markku Ruotsilaa, joka on puolustanut yhdysvaltain kristillisen oikeiston "koherenttia" maailmankuvaa. Pyysiäinen huomauttaa osuvasti, että myös Aku Ankan maailmankuva saattaa olla koherentti, mutta koherenttius ei tee siitä yhtään sen todellisempaa. Kristilliset uskomukset muuttuvat ongelmallisiksi, mikäli niitä "ei voida arvioida samoin kuin mitä tahansa väitteitä" (s. 111) - siis koherenssinäkökulmaa laajemmasta perspektiivistä.

Kuten sanottu, Pyysiäisen argumentaatiostrategia on Dawkinsia ja kumppaneita sofistikoituneempi siinä mielessä, että hän erottaa uskon- nolliset uskomukset uskonnosta elämäntapana. Toisaalta sopii kysyä, jääkö uskonnosta paljon jäljelle edes elämäntapana, mikäli sen perustavimmat uskomukset ovat virheellisiä. Pyysiäinen itse korostaa sitä, että uskovaiset käytännössä nojaavat tiettyihin totuusväittämiin - muuten uskonnolla ei olisi mitään käytännön merkitystä. Voisi siis kuvitella, että uskonnollisten uskomusten kritisoiminen johtaa väistämättä myös uskonnollisen elämäntavan kritiikkiin. Toki on myös niin, että ihmiset - sen paremmin uskovaiset kuin ateistitkaan - eivät jatkuvasti pohdi toimintansa syitä ja päämääriä, vaan toimivat ennemminkin tavanmukaisesti, ja tästä syystä uskonnollinen elämäntapa voi sinnitellä vaikka sen informaatiosisältö olisikin tyhjentynyt merkityksestä.

Pyysiäisen kulttuurintutkijoille ja uskontotieteilijöille esittämä kritiikki on jossain määrin osuvaa. Näiden tutkijoiden "tapa suhteellistaa kaikki on johtanut liian monet ajattelemaan, että ei ole mitään totuutta ja että asioiden järkiperäinen tarkastelu on vain pahasta" (s. 112). Tilanne on kieltämättä hyvin absurdi, mikäli tutkijat pitävät kaikkia uskomuksia samanarvoisina. Tähän täytyy kuitenkin lisätä, että kaikelta tutkimukselta ei voida vaatia uskomusten totuusarvojen selvittämistä. Esimerkiksi tiedonsosiologi - tai uskontotieteilijä - voi aivan hyvin tutkia erilaisia yhteiskunnassa vallitsevia uskomuksia ottamatta kantaa siihen, miten osuvia ne sattuvat kulloinkin olemaan. Relativismi voi siis olla perusteltua metodisista syistä, mutta tähän sen pätevyysalue rajoittuukin.

Kirjan keskeinen ongelma liittyy sen hajanaiseen ja epätasaiseen sisältöön. Melkein kolmasosa lyhyestä kirjasta nimittäin referoi erilaisia riivauksiksi kuviteltuja tapauksia. Nämä riivauskuvaukset alkavat pian puuduttaa lukijaa - etenkin kun Pyysiäinen ei missään vaiheessa vaivaudu selittämään, miten nämä tarinat liittyvät kirjan kokonaisuuteen. Ilmeisesti tarkoitus on vain osoittaa, että kaikkea hassua ne katoliset ovat uskoneet. Vaikka teos onkin tarkoitettu pamfletiksi eikä systemaattiseksi esitykseksi, olisi sen kokonaisuutta silti voinut miettiä tarkemmin. Puutteistaan huolimatta kirja on kiinnostava ja rohkea puheenvuoro, vaikka se ei varsinaisesti tuo keskusteluun mitään uutta verrattuna Dawkinsin ja kumppanien kiistakirjoituksiin. Olisikin ollut kiinnostavaa kuulla pohdintoja suomalaisen uskonnollisuuden erityispiirteistä. Suomi nimittäin lienee hyvä esimerkki siitä, miten rituaalit voivat jatkaa elämäänsä, vaikka uskonto ei itse uskomusten muodossa kovin monia enää vakuuttaisikaan.

Antti Gronow 